\title{
Overlying Strata Movement Laws Induced by Longwall Mining of Deep Buried Coal Seam with Superhigh-Water Material Backfilling Technology
}

\author{
Fangtian Wang $\mathbb{D}^{1,2}$ Qi Ma $\mathbb{D}^{1},{ }^{1}$ Gang $L i \mathbb{D}^{1},{ }^{1}$ Chengguo $W u,{ }^{3}$ and Guangli Guo ${ }^{4}$ \\ ${ }^{1}$ School of Mines, State Key Laboratory of Coal Resources and Safe Mining, Key Laboratory of Deep Coal Resource Mining, \\ Ministry of Education of China, China University of Mining and Technology, Xuzhou 221116, China \\ ${ }^{2}$ Key Laboratory of Mine Geological Hazards Mechanism and Control, Xi'an 710054, China \\ ${ }^{3}$ Shandong Yineng Coal Mine Co., Ltd., Jining 272511, China \\ ${ }^{4}$ School of Environment Science and Spatial Informatics, China University of Mining and Technology, Xuzhou 221116, China \\ Correspondence should be addressed to Fangtian Wang; wangfangtian111@163.com and Qi Ma; cumtckgc@163.com
}

Received 21 July 2018; Accepted 20 September 2018; Published 12 November 2018

Guest Editor: Dengke Wang

Copyright ( $\odot 2018$ Fangtian Wang et al. This is an open access article distributed under the Creative Commons Attribution License, which permits unrestricted use, distribution, and reproduction in any medium, provided the original work is properly cited.

\begin{abstract}
The "Three Under Mining" (mining under the buildings, the railways, and the waters) coal resources are stored in the central and eastern China. Many large-scale mine disasters occurred due to overburden strata movement and surface subsidence. Longwall mining with superhigh-water material backfilling technology has been improved efficiently to prevent the underground disasters and protect the surface ecological environment. Since underground mine pressure behavior and overlying strata movement are influenced by the backfilling strength and backfilling rates, rational design of backfilling parameters is key to realize the green mining of deep buried coal seams. Based on the combination of geological and production conditions of a deep buried coal seam with composite beam theory, the roof fracture distance was analyzed. The software of UDEC was used to simulate the overlying strata movement laws affected by the different backfilling strength and backfilling rates. With the comparative analysis of the vertical displacement movements and the vertical stress distributions, the reasonable filling rate and water volume fraction were determined to be $90 \%$ and $95 \%$, respectively. According to the field experiments, the underground dynamic load was low enough for the safe mining, and the village building can be kept in a stable state with the application of the backfilling technology. The research results in a scientific basis for the coordinated development between the safe and efficient mining of deep buried coal resources and protection of the surface ecological environment.
\end{abstract}

\section{Introduction}

The "Three Under Mining" (mining under the buildings, the railways, and the waters) coal reserves have been reached 13.79 billion tons in China, and the coal resources under the buildings are over 8.76 billion tons. The coal mines located in the central and eastern China mining areas are mostly accompanied by the congregate village buildings. As a result, the mining of the "Three Under Mining" coal resources is restricted by the protection of surface ecological environment $[1,2]$. Additionally, with the tens or almost one hundred years of exploitation, many central and eastern coal mines have entered into deep buried coal seams mining (elevation over $800 \mathrm{~m}$ ), which leads to a series issues, such as high geo-stress, high water pressure, high ground temperature, and high gas pressure [3-6]. Many in situ experiments show that longwall mining with backfilling technology is an efficient way to prevent the underground disasters and protect the surface ecological environment [7]. However, the field application effects and reliabilities are affected by many factors, including backfilling strength and backfilling rates.

Domestic and overseas scholars have carried out a series of studies on the backfilling technology and overlying strata movement laws. Mkadmi et al. [8] used the SIGMA/W finite element code to simulate the characteristics of the rock- 
backfill interface influence on the magnitude of the stresses in backfilled stopes. Mohamed et al. [9] simulated the influence of filling gables on the long-term stability of gypsum cylinders in order to prevent the collapse of surface buildings and infrastructure. Kostecki and Spearing [10] used the FLAC $^{3 \mathrm{D}}$ software to analyze the plastic flow characteristics of coal pillars and compared the shear strength, tensile strength, and the influence of mine space constraints on the strength of coal pillars. In China, hydraulic backfilling, solid waste backfilling, paste-like backfilling, and superhigh-water material (SHWM) backfilling have been employed in many underground coal mines. The field observations indicate that (1) the hydraulic backfilling technology has a good surface subsidence control effect, but it has no general applications due to complicated system and high cost [11]. (2) The backfilling rate of the solid waste backfilling technology has increased to $85 \%$, which benefits long-term stability for surface subsidence. However, it cannot meet the requirement of large area longwall mining due to high investment, lack of solid waste material [12]. (3) Paste-like backfilling technology has high security, high mining rate, and good surface subsidence control effect, and is environment friendly, which also has many disadvantages, such as high initial investment and high production cost [13]. (4) Superhigh-water material backfilling technology has many prominent advantages besides low initial investment, low production cost, simple backfilling process, easy operation, and good backfilling material mechanics, which are of great help to high-efficient mining and effective surface subsidence control $[14,15]$. For the research of overlying movement laws, Li et al. [16] applied the elastic foundation thin plate theory to presenting that the elastic foundation coefficient is the key factor affecting the movement and deformation of overburden during backfilling mining. Jia et al. [17] carried out a physical simulation experiment of superhigh-water material (SHWM) backfilling technology, which illustrated the laws of overburden migration and surface subsidence. Yang et al. [18] analyzed the influence of different backfilling strength and backfilling rates on the overburden movement and deformation. The research studies mentioned above can shed light on revealing the overlying strata movement laws of longwall mining in deep buried coal seams.

Based on the typical geological and production conditions of AB Coal Mine, the theoretical analysis, numerical simulation, and in situ measurement were comprehensively applied to uncover the overlying strata movement laws of longwall mining in deep buried coal seams with SHWM backfilling technology. The reasonable parameters, including backfilling rates and water volume fraction, are determined to guarantee the safe and efficient mining of deep buried coal resources and protection of the surface ecological environment.

\section{Engineering Background}

AB Coal Mine is located in Shandong Province, an eastern China mining area. The No. 3 coal seam, mined in the CG1302 working face, has an average thickness of $3.0 \mathrm{~m}$. The geological structure is simple in the longwall panel, the advancing length of the CG1302 working face is $1030 \mathrm{~m}$, and the inclination length is $110 \mathrm{~m}$. The ground elevation is about $+47 \mathrm{~m}$; the underground elevation is about $-776.7 \mathrm{~m}$, and thus, the buried depth is over $820 \mathrm{~m}$, which means high geo-stress, high water pressure, high ground temperature, and high gas pressure increasingly emerge during longwall mining. The coal seam comprehensive histogram and UDEC numerical simulation model are shown in Figure 1. The mechanical parameters of the rock layer are illustrated in Table 1.

More than 1790 village buildings are concentrated on the surface of AB Coal Mine, which is a typical "Three Under Mining." To achieve the goal of the safe and efficient mining of deep coal resources and the protection of the surface ecological environment, the longwall mining with SHWM backfilling technology was applied in the CG1302 working face. When the working face advances, the backfilling package will be hung up and injected with mixed SHWM in the goaf immediately behind the hydraulic support. After the mixed SHWM solidified, the mined out roof will be supported by the SHWM backfilling and the left coal pillars. The backfilling technology procedure and field application are shown in Figure 2.

\section{Theoretical Analysis}

The roof, hanging in the goaf after the working face advancing, has a load composed by both self-weight and the overlying strata load. The interaction between the overlying strata forms a composite beam structure, according to the combined beam theory [19], and the overburden load is

$$
\left(q_{n}\right)_{1}=\frac{E_{1} h_{1}^{3}\left(\gamma_{1} h_{1}+\gamma_{2} h_{2}+\cdots+\gamma_{n} h_{n}\right)}{E_{1} h_{1}^{3}+E_{2} h_{2}^{3}+\cdots+E_{n} h_{n}^{3}},
$$

where $\left(q_{n}\right)_{1}$ is the load that acts on the first layer with the consideration of the $n^{\text {th }}$ layer, MPa; $E_{n}$ is the elastic modulus of the $n^{\text {th }}$ layer, $\mathrm{MPa} ; H_{n}$ is the thickness of the $n^{\text {th }}$ layer, m; and $\gamma_{n}$ is the bulk density of the $n^{\text {th }}$ layer, $\mathrm{MN} / \mathrm{m}^{3}$.

According to the combined beam theory, the load that acts on the immediate roof is calculated to be $0.141 \mathrm{MPa}$, and the load that acts on the main roof is $0.289 \mathrm{MPa}$. Before the first fracturing of the roof, the coal wall behind the open-off cut and in front of the working face forms a fixed beam structure, as shown in Figure 3.

According to the elastic mechanics theory, the maximum shear stress emerges in the center of the end-fixed beam. According to the maximum tensile stress criterion of the rock, the length before the fracture is [20]

$$
L \leq 2 h \sqrt{\frac{[\sigma]}{q}-\frac{1}{5}} .
$$

When the roof is fractured, the safety factor is $n$, and the length before the fracture is

$$
L_{s} \leq 2 h \sqrt{\frac{[\sigma]}{n q}-\frac{1}{5}}
$$




\begin{tabular}{|c|c|c|c|c|c|}
\hline No. & Thickness (m) & Depth (m) & Lithology description & & \\
\hline 1 & 9.0 & 714.5 & Mudstone & 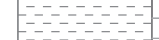 & \\
\hline 2 & 16.0 & 723.5 & Sandy mudstone & & \\
\hline 3 & 8.1 & 739.3 & Fine sandstone & $\Xi \Xi \Xi$ & \\
\hline 4 & 1.9 & 747.4 & Medium sandstone & & \\
\hline 5 & 9.2 & 749.3 & Mudstone & - & \\
\hline 6 & 2.4 & 758.5 & Mudstone & & \\
\hline 7 & 8.8 & 760.9 & Mudstone & & \\
\hline 8 & 2.8 & 769.7 & Sandy mudstone & & \\
\hline 9 & 4.8 & 772.5 & Sandy mudstone & & \\
\hline 10 & 4.9 & 777.3 & Mudstone & & \\
\hline 11 & 5.0 & 782.2 & Fine sandstone & & \\
\hline 12 & 4.2 & 787.2 & Siltstone & 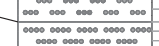 & \\
\hline 13 & 10.8 & 791.4 & Fine sandstone & 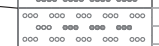 & 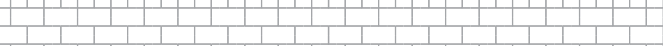 \\
\hline 14 & 10.5 & 802.2 & Fine sandstone & & 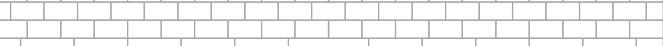 \\
\hline 15 & 2.6 & 812.7 & Siltstone & & 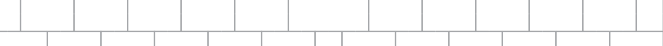 \\
\hline 16 & 4.0 & 815.3 & Fine sandstone & & 1 \\
\hline 17 & 3.0 & 819.3 & No.3 coal seam & $\begin{array}{lll} & 1\end{array}$ & 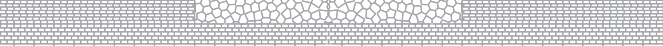 \\
\hline 18 & 1.7 & 824.0 & Mudstone & $\begin{array}{lll} & \end{array}$ & 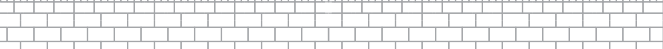 \\
\hline 19 & 10.5 & 834.5 & Fine sandstone & 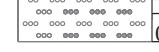 & $\begin{array}{llllllllllll}0 & 10 & 20 & 30 & 40 & 50 & 200 & 210 & 220 & 230 & 240\end{array}$ \\
\hline
\end{tabular}

FIGURE 1: Coal seam comprehensive histogram and UDEC numerical simulation model.

TABLE 1: Mechanical parameters of coal seam and overlying strata.

\begin{tabular}{|c|c|c|c|c|c|c|c|}
\hline No. & Lithology & $\begin{array}{c}\text { Density } \\
\left(\mathrm{kg} \cdot \mathrm{m}^{-3}\right)\end{array}$ & $\begin{array}{l}\text { Bulk modulus } \\
\text { (GPa) }\end{array}$ & $\begin{array}{c}\text { Tensile strength } \\
(\mathrm{MPa})\end{array}$ & $\begin{array}{l}\text { Shear modulus } \\
(\mathrm{GPa})\end{array}$ & $\begin{array}{c}\text { Cohesion } \\
(\mathrm{MPa})\end{array}$ & Friction angle $\left({ }^{\circ}\right)$ \\
\hline 1 & Fine sandstone & 2597 & 7.2 & 3.13 & 4.9 & 12.0 & 36 \\
\hline 2 & Mudstone & 2529 & 7.5 & 1.38 & 3.0 & 12.0 & 26 \\
\hline 3 & No. 3 coal seam & 1540 & 5.8 & 1.25 & 1.2 & 3.0 & 33 \\
\hline 4 & Siltstone & 2575 & 5.8 & 1.90 & 3.6 & 17.0 & 40 \\
\hline 5 & Sandy mudstone & 2500 & 5.7 & 0.21 & 3.4 & 1.3 & 30 \\
\hline 6 & Medium sandstone & 2660 & 7.0 & 1.03 & 4.2 & 13.0 & 44 \\
\hline
\end{tabular}

where $L_{\mathrm{s}}$ is the roof stability length, $\mathrm{m} ;[\sigma]$ is the roof tensile strength, MPa; $n$ is the safety factor; and $q$ is the load acts on the roof, $\mathrm{MPa}$.

When the roof beam fracturing, the maximum bending deflection equation for the center section is

$$
\omega_{\max }=\frac{q l^{4}}{384 E I},
$$

where $\omega_{\max }$ is the maximum bending deflection; $I$ is the moment of inertia, $\mathrm{m}^{4} ; I=b h^{3} / 12, b$ is the beam width, $\mathrm{m}$ and $h$ is the beam height, $\mathrm{m}$; and $l$ is the length of the hanging roof, $\mathrm{m}$.

After the first fracture of the roof strata, the beam structure is in a state of one end fixed and another end hanged, forming a cantilever beam structure. The safe length of the cantilever beam before fracture is [21]

$$
l \leq \sqrt{\frac{5 h^{2}[\sigma]+q h^{2}}{15 q}},
$$

where $l$ is the period weighting length of roof strata, m.

According to the mechanical parameters of coal and rock strata of the CG1302 working face, most of the rock strata have large thickness and damage due to brittle failure.
Therefore, the safety factor $n$ can be determined to be 1.2. As a result, the first roof weighting lengths of the immediate roof and the main roof are $29.7 \mathrm{~m}$ and $63.0 \mathrm{~m}$, and the period roof weighting lengths are $9.5 \mathrm{~m}$ and $20.3 \mathrm{~m}$, respectively.

In addition, with the consideration of the maximum vertical bending values of the immediate roof and the main roof are $0.26 \mathrm{~m}$ and $0.48 \mathrm{~m}$, and the residual expansion coefficient of the rock is 1.15 and the maximum bending value of the main roof can reach $0.48 \mathrm{~m}$ and become fracture while the backfilling height reaches $1.53 \mathrm{~m}$. The critical backfilling rate to prevent main roof fracturing is $51.0 \%$, and the immediate roof will fracture if the backfilling rate is less than $91.3 \%$.

\section{Numerical Simulation of Overlying Strata Movement Laws}

4.1. Establishment of the Numerical Simulation Model. The software of UDEC (Universal Distinct Element Code) was applied to analyzing the overlying strata movement laws. As shown in Figure 1, the numerical model has a length and a height of $240 \mathrm{~m}$ and $120 \mathrm{~m}$, respectively. According to the geological conditions, the upper boundary stress is set to 17.86 MPa to simulate the weight of the overlying strata. The 


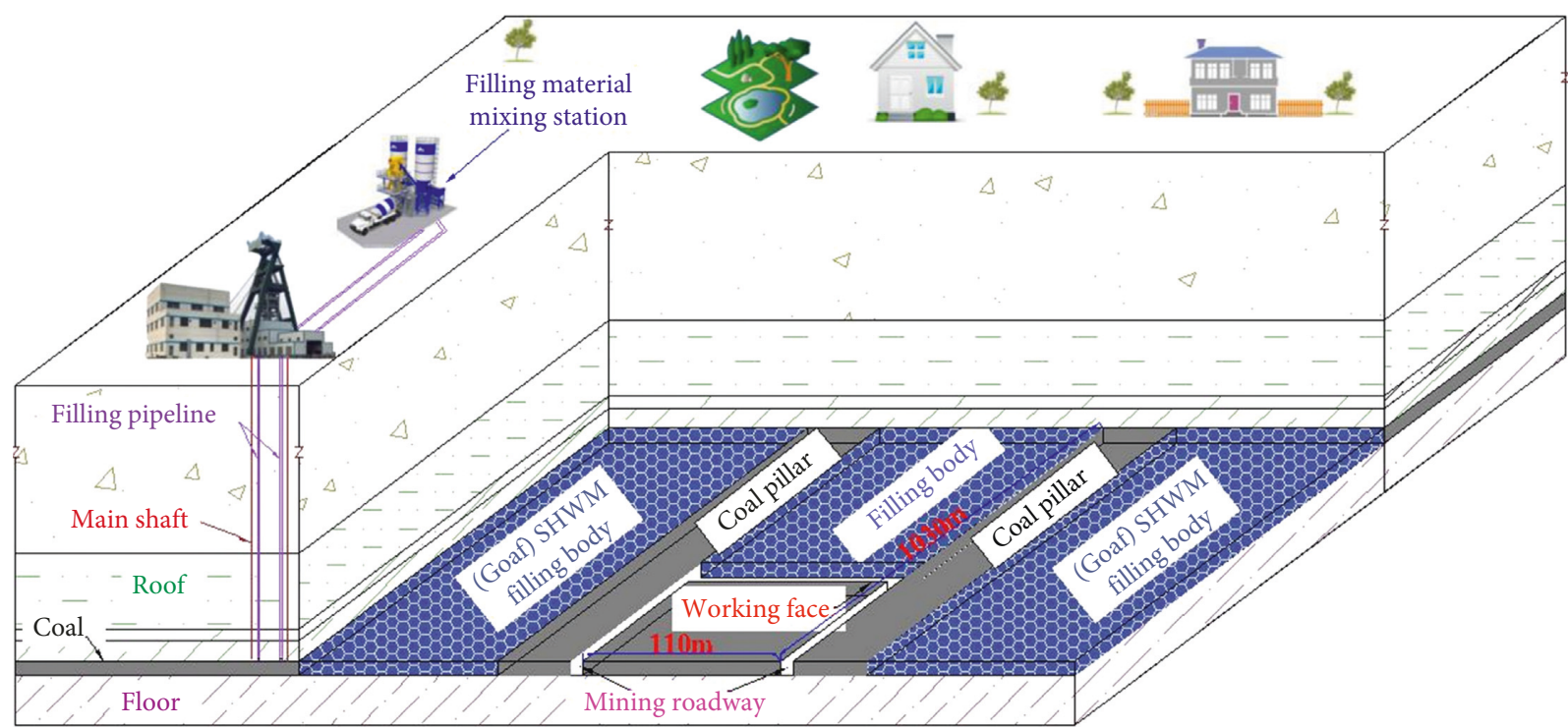

(a)

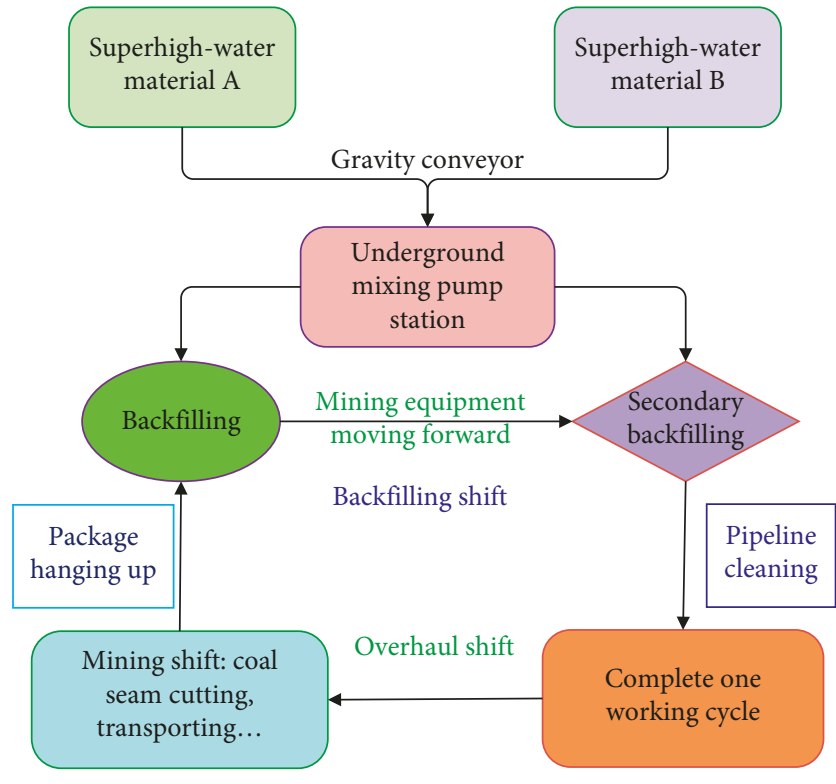

(b)

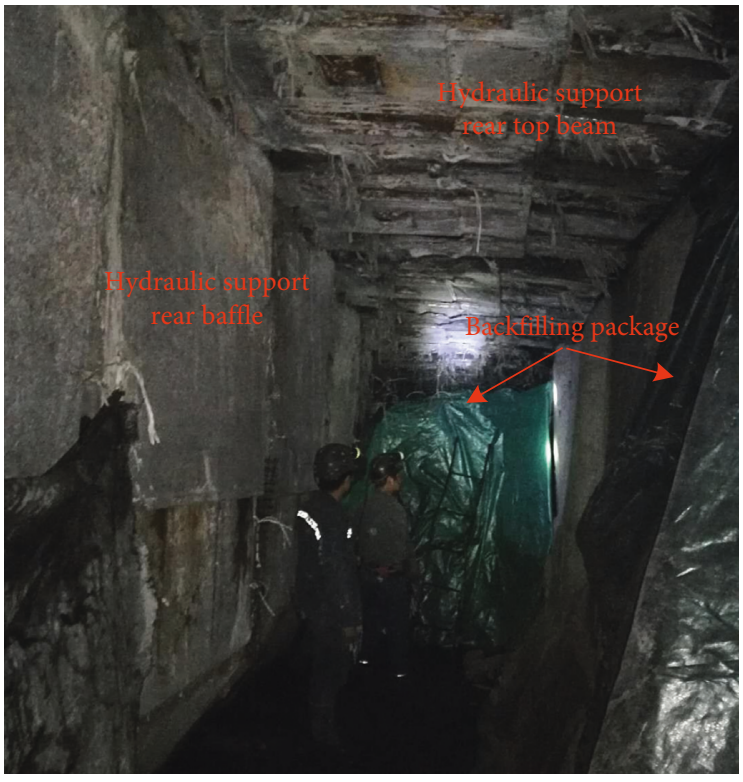

(c)

FIGURE 2: SHWM backfilling procedure and its application. (a) SHWM backfilling for the "Three Under Mining." (b) Procedure of SHWM backfilling technology. (c) Field experiment of SHWM backfilling technology.

simulated longwall mining face advancing from 50 to $190 \mathrm{~m}$ with a total mining length of $140 \mathrm{~m}$. The ZC7000/19/40 type hydraulic support is used in the CG1302 working face, the supporting strength is $0.67 \mathrm{MPa}$, and the support length is $4 \mathrm{~m}$. The simulation contents include the vertical displacement movement laws, the plastic zone development characteristics, and the vertical stress evolutions mechanism, which vary with different roof manage modes, including roof caving and backfilling.

\subsection{Numerical Simulation Results}

4.2.1. Vertical Displacement Movement Laws. As shown in Figure 4, (1) the immediate roof is bended when the working face advances $30 \mathrm{~m}$, and then fractured and caved into goaf when the working face advances $35 \mathrm{~m}$. (2) The main roof is fractured when the working face advances 60-70 m. (3) After the backfilling in the goaf, the immediate roof is not fractured when the working face advances $35 \mathrm{~m}$ and $70 \mathrm{~m}$, and the vertical displacement is less than $0.3 \mathrm{~m}$.

To predict the surface subsidence under different filling rates, a survey line, used to monitor the vertical displacement, was set on the top of the UDEC numerical simulation model. As shown in Figure 5, in the condition of nonbackfilling, the maximum vertical displacement was above $0.95 \mathrm{~m}$. With the increase of filling rate from $40 \%$ to $90 \%$, the vertical displacement decreased from $0.76 \mathrm{~m}$ to $0.22 \mathrm{~m}$. It can be predicted that the surface subsidence will be effectively 


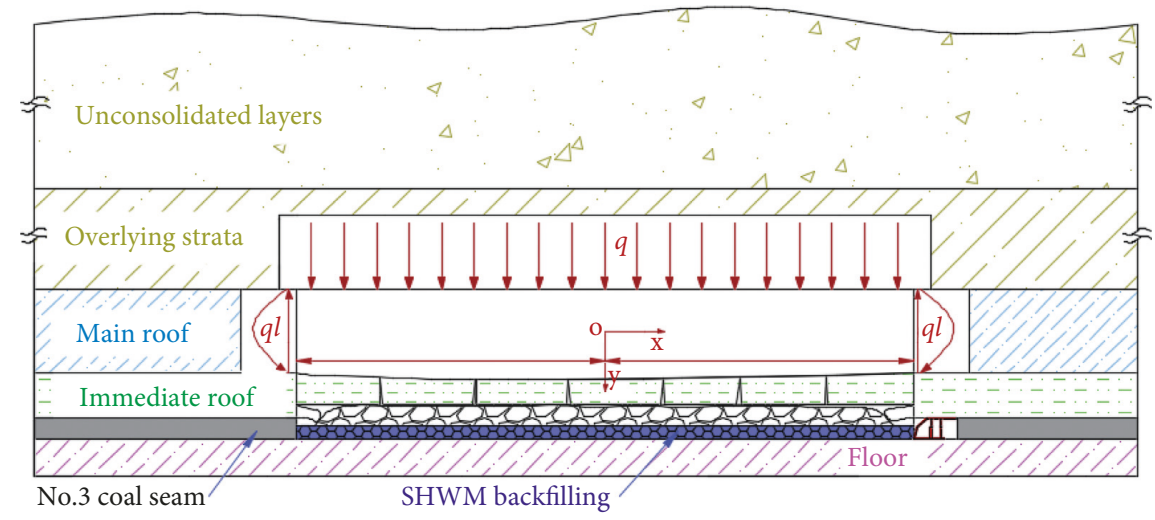

FIGURE 3: Overlying mechanical structure model.

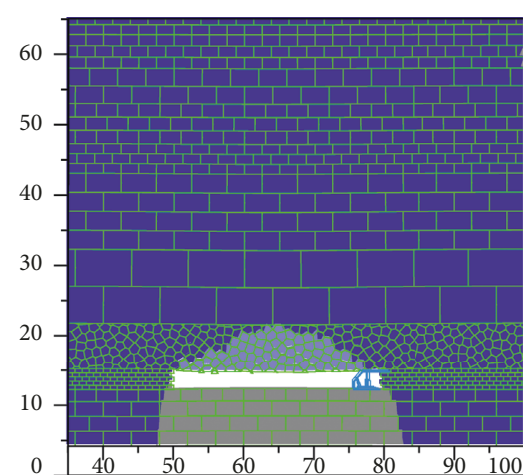

(a)

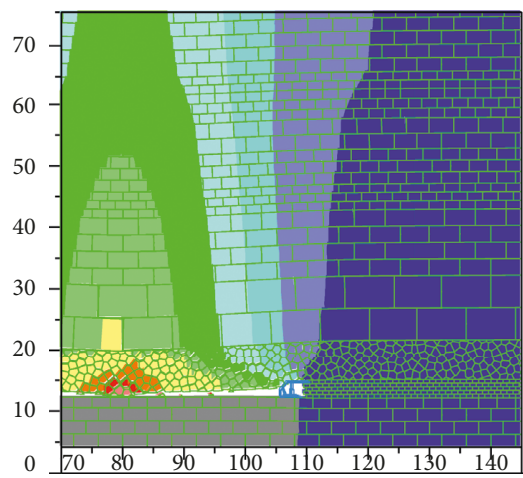

(d)

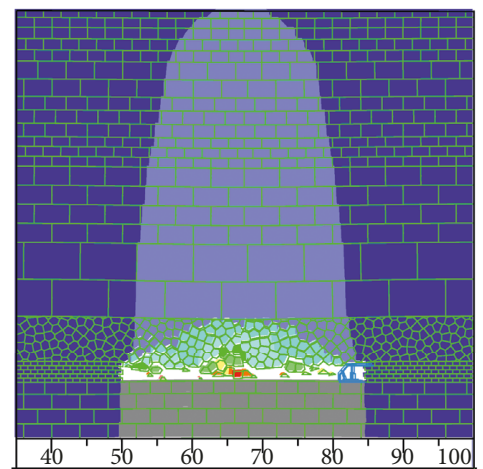

(b)

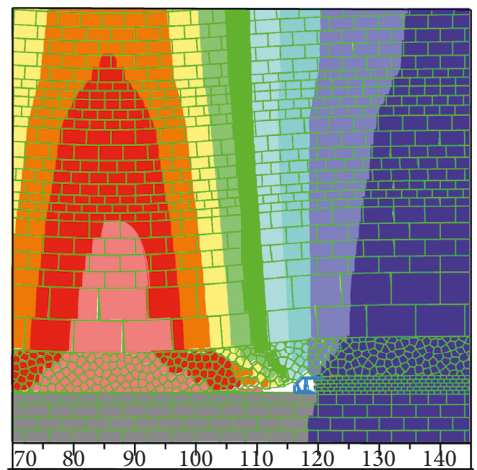

(e)

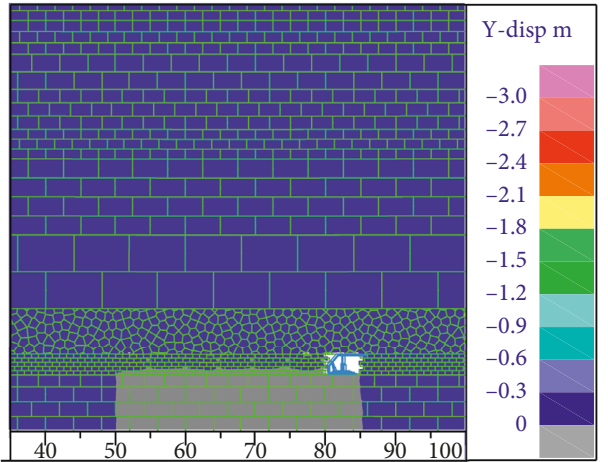

(c)

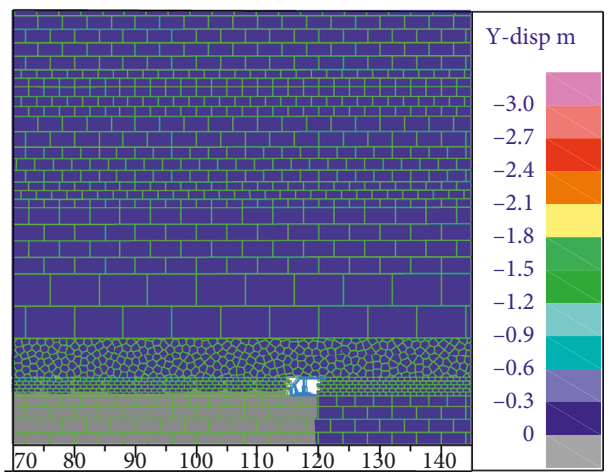

(f)

Figure 4: Vertical displacements of overlying strata in different roof management methods. (a) Nonbackfilling excavation $30 \mathrm{~m}$. (b) Nonbackfilling excavation $35 \mathrm{~m}$. (c) Backfilling excavation $35 \mathrm{~m}$. (d) Nonbackfilling excavation $60 \mathrm{~m}$. (e) Nonbackfilling excavation 70 m. (f) Backfilling excavation $70 \mathrm{~m}$.

controlled by the increase of the filling rate, not less than $90 \%$.

\subsubsection{Plastic Zone Development Characteristics. As shown in} Figure 6, (1) in the condition of nonbackfilling, the plastic zones development increases explicitly in the immediate roof and the main roof when the working face advances from $30 \mathrm{~m}$ to $70 \mathrm{~m}$ : the maximum height of the plastic zone development in the central goaf increases from $28 \mathrm{~m}$ to $40 \mathrm{~m}$ while the working face advances from $60 \mathrm{~m}$ to $70 \mathrm{~m}$. (2) When zones first emerge in the overlying strata around the working face, the immediate roof, the main roof, and the overlying strata start to bend and fracture in proper order. Additionally, the plastic failure zone formed a shape similar to "reverse funnel" above the goaf. (3) In the condition of backfilling, the plastic zones have no significant change when the working face advances from $35 \mathrm{~m}$ to $70 \mathrm{~m}$; the plastic zones only occurred within the immediate roof, and the plastic damage degree was not large enough to break the main roof.

4.2.3. Vertical Stress Evolutions Mechanism. As shown in Figure 7, (1) a "butterfly wings" shape vertical stress accumulation area was formed both in front of the working face and behind the open-off cut, and the stress-relaxed area was 


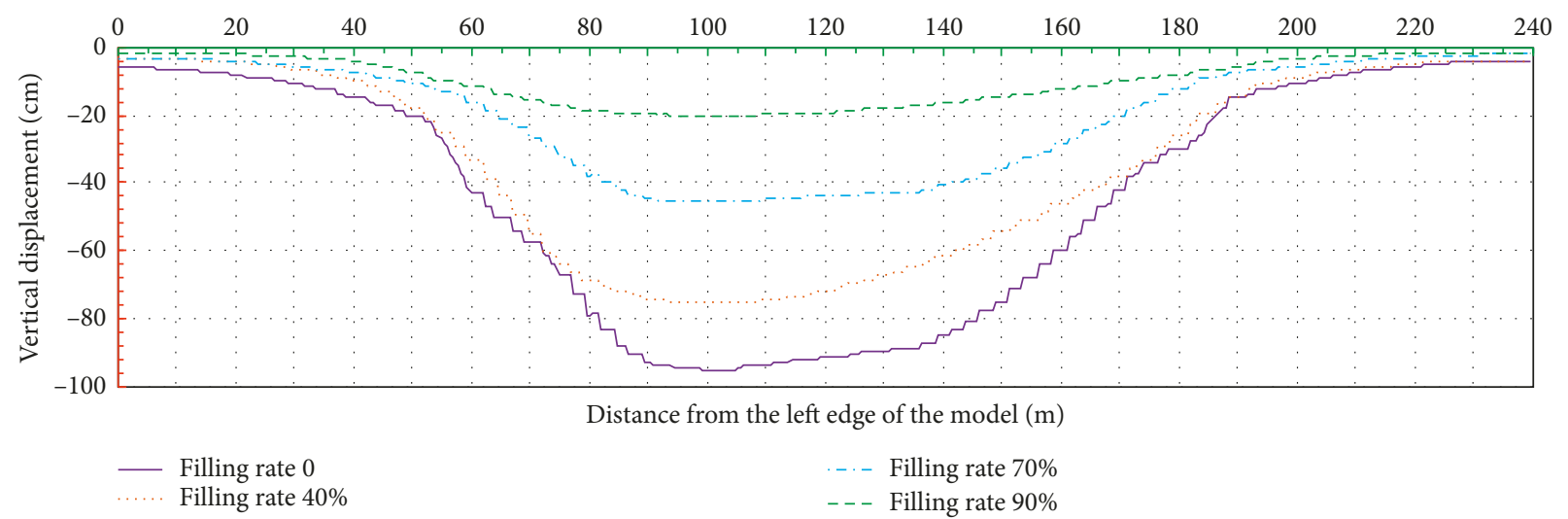

FIGURE 5: Vertical displacement curves vary with different filling rates.

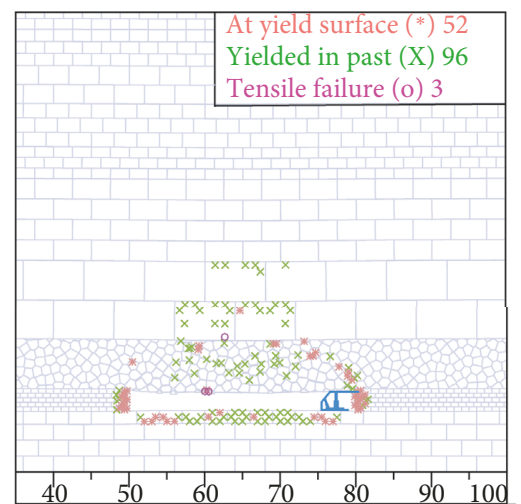

(a)

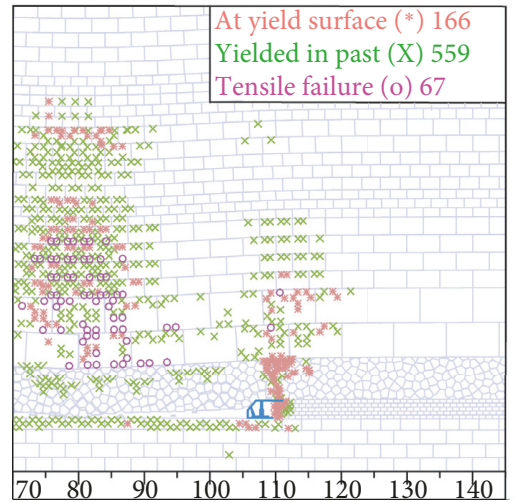

(d)

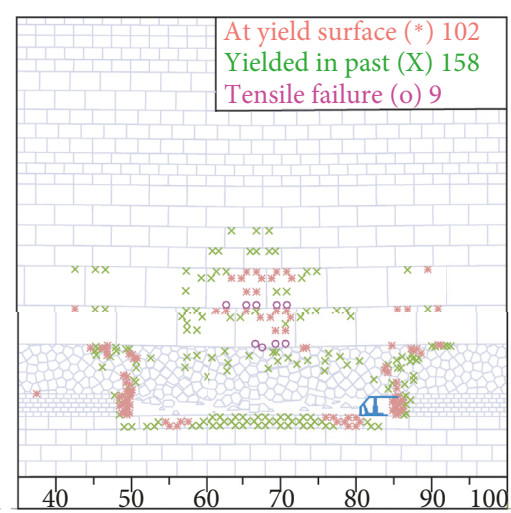

(b)

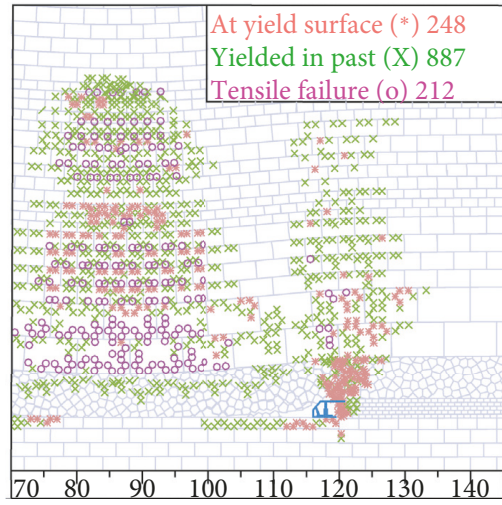

(e)

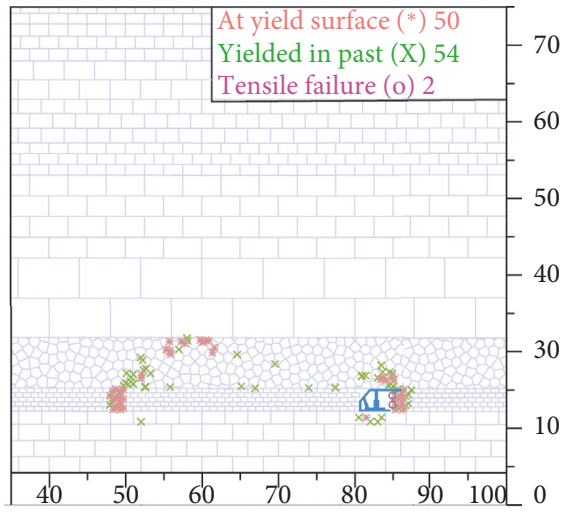

(c)

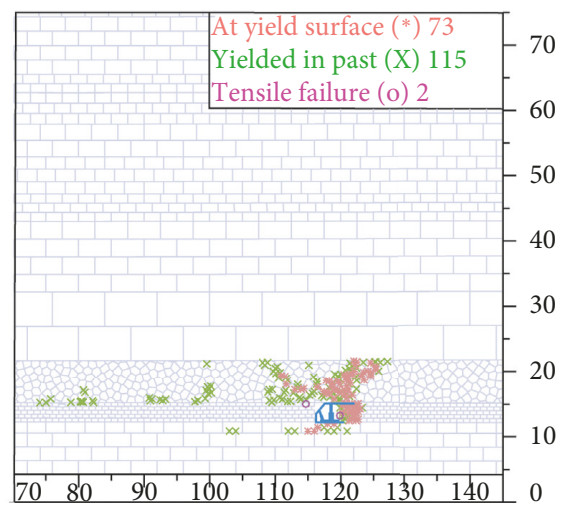

(f)

Figure 6: Plastic zones development in different roof management methods. (a) Nonbackfilling excavation $30 \mathrm{~m}$. (b) Nonbackfilling excavation $35 \mathrm{~m}$. (c) Backfilling excavation $35 \mathrm{~m}$. (d) Nonbackfilling excavation $60 \mathrm{~m}$. (e) Nonbackfilling excavation $70 \mathrm{~m}$. (f) Backfilling excavation $70 \mathrm{~m}$.

developed overlying the goaf. (2) In the condition of nonbackfilling, the concentrated vertical stresses in front of the working face were about $45 \mathrm{MPa}, 48 \mathrm{MPa}$, and $54 \mathrm{MPa}$, with the concentrate rates of $2.32,2.48$, and 2.78 , when the working face advances $30 \mathrm{~m}, 35 \mathrm{~m}$, and $60 \mathrm{~m}$, respectively. The large concentrated vertical stress means huge elastic deformation energy was involved around the working face, which is likely to incur rock burst accidents and threaten the miners' life. (3) After the backfilling in the goaf, the concentrated vertical stress had no such significant increase compared to nonbackfilling, because the backfilling body in the goaf supported the bended roof and shared the mininginduced vertical stress, which played a significant effect to decrease the stress concentrate rate around the goaf and prevent the rock burst disasters.

As shown in Figure 8(a), in the case of nonbackfilling, the peak values of the vertical stress, distributed in front of the longwall mining face, were $44.5 \mathrm{MPa}, 54.0 \mathrm{MPa}$, 


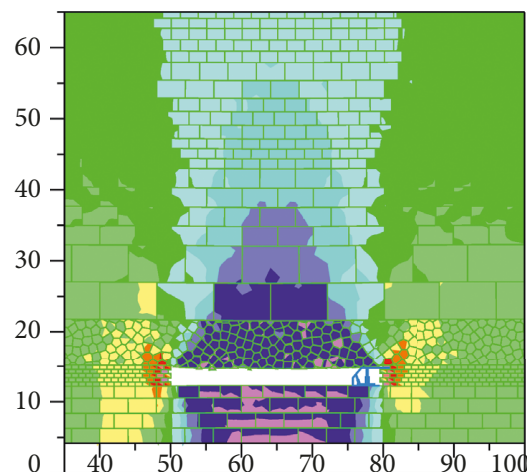

(a)

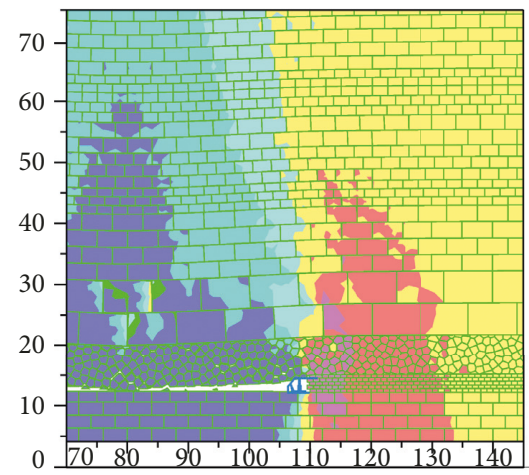

(d)

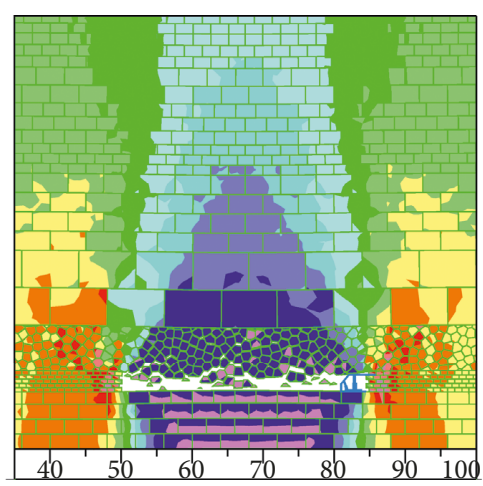

(b)

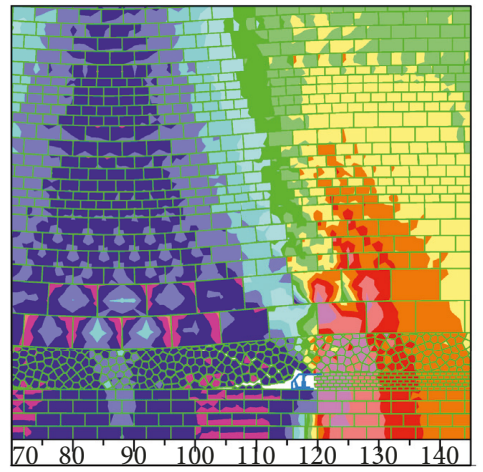

(e)

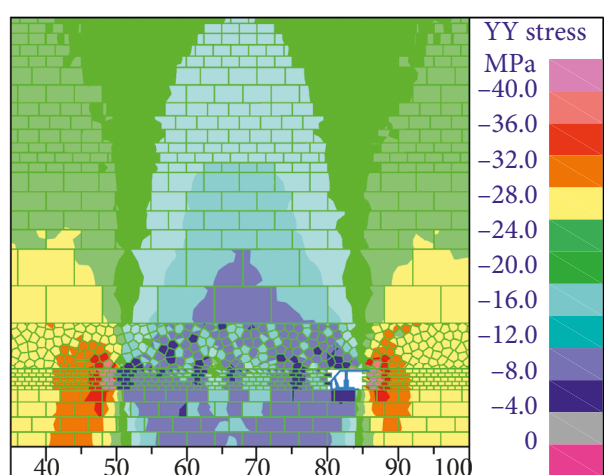

(c)

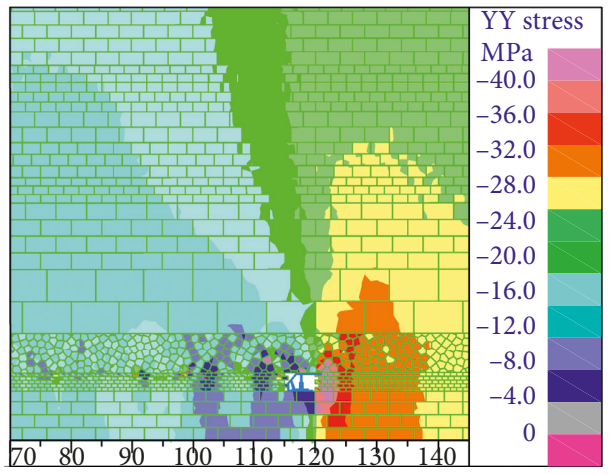

(f)

Figure 7: Vertical stress distribution characteristics of process stope under different roof management methods. (a) Nonbackfilling excavation $30 \mathrm{~m}$. (b) Nonbackfilling excavation $35 \mathrm{~m}$. (c) Backfilling excavation $35 \mathrm{~m}$. (d) Nonbackfilling excavation $60 \mathrm{~m}$. (e) Nonbackfilling excavation $70 \mathrm{~m}$. (f) Backfilling excavation $70 \mathrm{~m}$.

60.0 $\mathrm{MPa}$, and 59.2 $\mathrm{MPa}$ when the working face advances $30 \mathrm{~m}, 60 \mathrm{~m}, 90 \mathrm{~m}$, and $120 \mathrm{~m}$, respectively. Due to the immediate roof, the main roof fracturing, and caving into the goaf, caused by the longwall mining, the vertical stress was gradually increasing with the increase of advancing length, and then reached a stable state. As shown in Figure 8(b), in the case of the working face advancing length of $140 \mathrm{~m}$ with the application of superhigh-water filling in the goaf, the peak values of the vertical stress were $44.0 \mathrm{MPa}, 47.2 \mathrm{MPa}$, $57.1 \mathrm{MPa}$, and $60.5 \mathrm{MPa}$ when the filling rates were $90 \%$, $70 \%, 40 \%$, and 0 , respectively. As the filling rate increases, the peak value of the vertical stress in front of the coal wall decreases gradually. It can reveal that the better control of both coal wall splitting and roadway surrounding rock deformation would be achieved through increasing the filling rate. As shown in Figure 8(c), the peak values of the vertical stress were $39.7 \mathrm{MPa}, 43.6 \mathrm{MPa}, 45.3 \mathrm{MPa}$, and $49.7 \mathrm{MPa}$ when the water volume fractions were $91 \%, 93 \%$, $95 \%$, and $97 \%$, respectively. Simultaneously, there were only low peak stress changes while the water volume fraction varies from $93 \%$ to $95 \%$. Considering the superhigh-water material costs and the pipeline delivery efficiency, the proper water volume fraction was determined to be $95 \%$.

\section{Field Experiments and Measurements}

5.1. Ground Pressure Measurements. The filling rate of $90 \%$ and the water volume fraction of $95 \%$ were used in the exploitation of the CG1302 working face. During the longwall mining with SHWM backfilling technology, a real-time digital ground pressure monitor was set up in the front column of the hydraulic support, which can capture the changes of the load acted on the hydraulic support. For example, the support resistance observations of the $53^{\#}$ hydraulic support are shown in Figure 9. According to the field measurement data, the average and maximum working resistances of the hydraulic support were $19.7 \mathrm{MPa}$ and $36.0 \mathrm{MPa}$, and the roof weighting criterion was determined to $28.1 \mathrm{MPa}$. Figure 9 also indicates that the average period roof weighting length of the immediate roof is $9.6 \mathrm{~m}$, which is verifying the reasonable of the theoretical analysis $(9.5 \mathrm{~m})$. With the application of the backfilling technology with a filling rate of $90 \%$, only the immediate roof has been fractured and caved into the goaf, and the dynamic load coefficient of the working face was low enough for the safe mining of the deep buried coal seam.

5.2. Surface Subsidence Measurements. To evaluate the effect of SHWM backfilling technology for controlling the surface subsidence, a total of 8 observation lines were arranged in the corresponding ground positions of CG1301 and CG1302. There are 17 measuring points in the survey lines, from $\mathrm{C} 1$ to $\mathrm{C} 17$, respectively. 


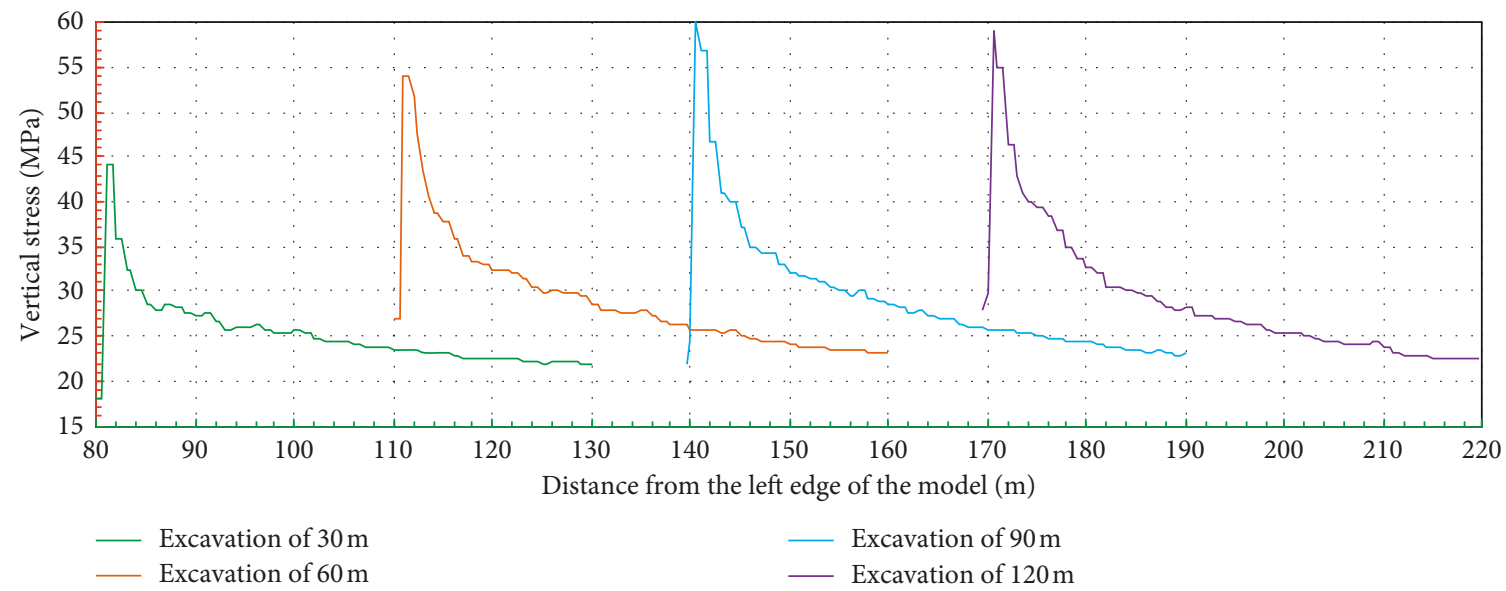

(a)

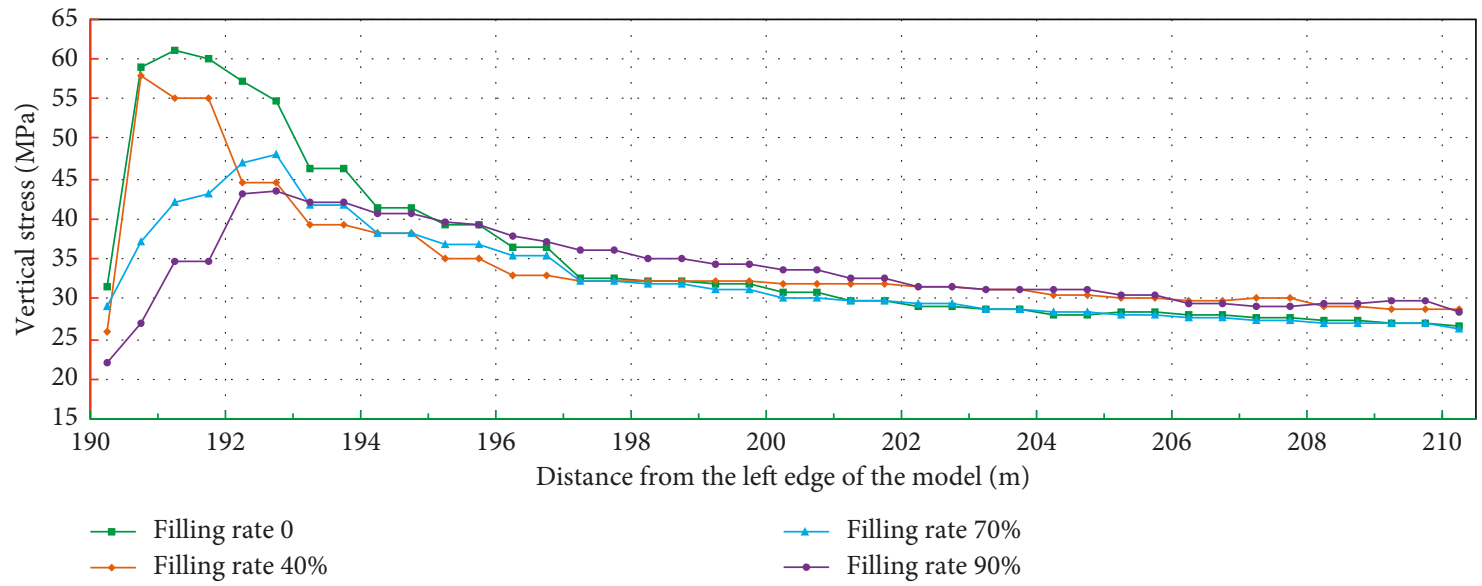

(b)

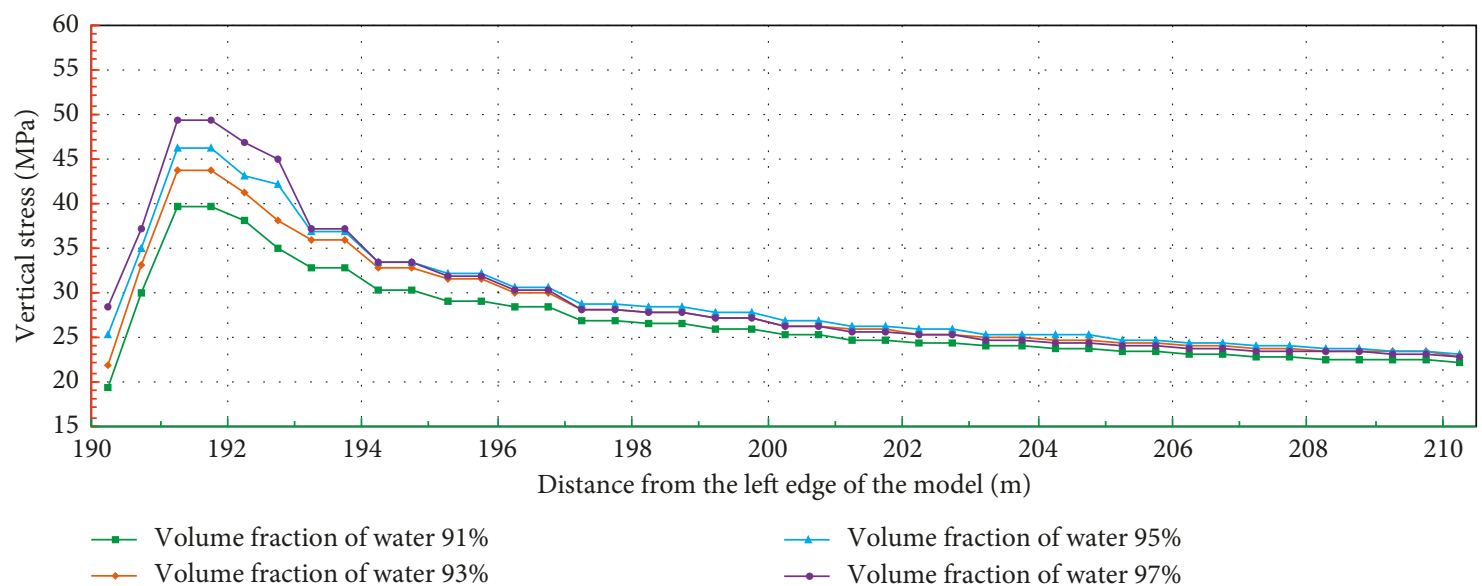

(c)

Figure 8: Concentrated vertical stress curves vary with excavation length and filling rate. (a) Different excavation length. (b) Different filling rate. (c) Different volume fraction of water.

As shown in Figure 10, the maximum cumulative dynamic subsidence of the $C$ line was less than $200 \mathrm{~mm}$, which is consistent with the numerical simulation results. The surface subsidence measurements results indicate that the village building can be kept in a stable state even affected by the underground longwall mining-induced overlying movements. It can be concluded that the goal of the safe and efficient mining of deep buried coal resources and protection of surface ecological environment would be realized for the "Three Under Mining" coal resources with the application of SHWM backfilling technology and reasonable filling parameters design. 


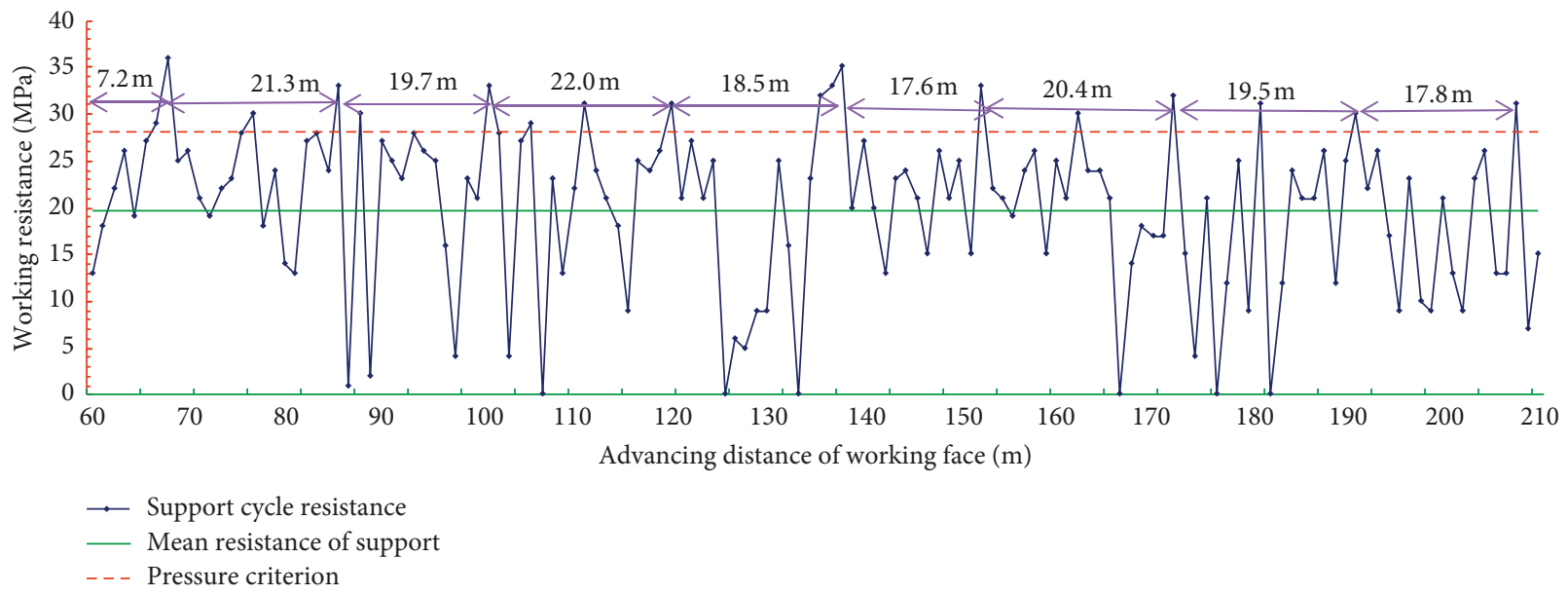

FIGURE 9: Support resistance change curves during the advancing of the backfilling face.

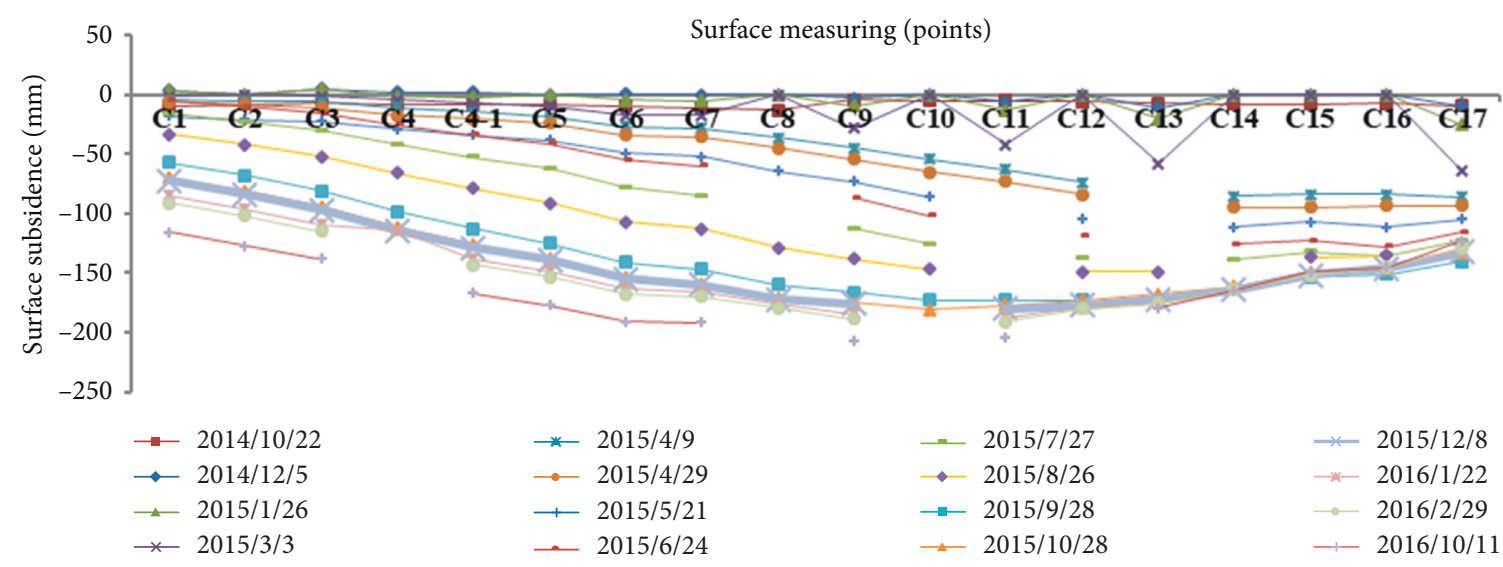

Figure 10: Record of dynamic subsidence of ground surface during working face mining.

\section{Conclusions}

(1) High geo-stress, high water pressure, high ground temperature, and high gas pressure increasingly emerge during longwall mining in deep buried coal seams. Longwall mining with superhigh-water material backfilling technology is one of the high-efficient ways to prevent the underground disasters and protect the surface ecological environment.

(2) The software of UDEC was applied to analyze the overlying strata movement laws. In the nonbackfilling conditions, the large concentrated vertical stress means a huge elastic deformation energy was involved around the working face, which was likely to cause rock burst accidents and threaten the miners' life. In contrast, the backfilling played a significant effect to decrease the stress concentrate rate around the goaf and prevent the rock burst disasters.

(3) With the comparisons of the vertical displacement movements and the vertical stress distributions, the reasonable parameters were determined, such as the filling rate of $90 \%$ and the water volume fraction of $95 \%$, which were carried out in the field experiments.
(4) According to the field measurement data, the underground dynamic load was low enough to enable the safe mining, and the village building can be kept in a stable state with the application of the backfilling technology. The aim of the safe and efficient mining of deep buried coal resources and protection of surface ecological environment would be achieved for exploiting the "Three Under Mining" coal resources.

\section{Data Availability}

The research data used to support the findings of this study are available from the corresponding author upon request.

\section{Conflicts of Interest}

The authors declare there are no conflicts of interest regarding the publication of this paper.

\section{Acknowledgments}

This work was supported by the Key Laboratory of Mine Geological Hazards Mechanism and Control (No. KF2018- 
02), the National Science Foundation for Postdoctoral Scientists of China (No. 2018M630634), the National Key R\&D Program of China (No. 2018YFC0604701), the visiting scholarship funded by the China Scholarship Council (No. 201802180034), and the Priority Academic Program Development of Jiangsu Higher Education Institutions. The authors gratefully acknowledge the financial support of the above-mentioned agencies.

\section{References}

[1] Y. Wu, "Effectiveness and development direction of filling mining technology in China's coal mines," China Coal, vol. 38 , no. 6, p. 266, 2012.

[2] F. K. Xu and F. M. Li, "Analysis on some problems for the mining of 'Three Downs' coal resources in China," Coal Economic Research, vol. 25, no. 5, pp. 26-27, 2005.

[3] H. P. Xie, J. H. Wang, and B. H. Shen, "New idea of coal mining scientific mining and sustainable mining capacity," Journal of China Coal Society, vol. 37, no. 7, pp. 1069-1079, 2012.

[4] H. P. Xie, "Research framework and anticipated results of deep rock mechanics and mining theory," Advanced Engineering Sciences, vol. 49, no. 2, pp. 1-16, 2017.

[5] G. Z. Yin, X. Li, J. Lu, and M. H. Li, "Disaster-causing mechanism of compound dynamic disaster in deep mining under static and dynamic load conditions," Journal of the China Coal Society, vol. 42, no. 9, pp. 2316-2326, 2017.

[6] C. H. Li, L. Bu, X. M. Wei et al., "Current status and future trends of deep mining safety mechanism and disaster prevention and control," Chinese Journal of Engineering, vol. 39, no. 8, pp. 1129-1140, 2017.

[7] G. M. Feng, Y. Ding, H. J. Zhu, and J. B. Bai, "Experimental research on a superhigh-water packing material for mining and its micromorphology," Journal of China University of Mining \& Technology, vol. 39, no. 6, pp. 813-819, 2010.

[8] N. E. Mkadmi, M. Aubertin, and L. Li, "Effect of drainage and sequential filling on the behavior of backfill," Canadian Geotechnical Journal, vol. 51, no. 1, pp. 1-15, 2014.

[9] M. A. H. Mohamed, D. Christophe, and M. Farimeh, "Improving short- and long-term stability of underground gypsum mine using partial and total backfill," Rock Mechanics and Rock Engineering, vol. 43, no. 4, pp. 447-461, 2010.

[10] T. Kostecki and A. J. S. Spearing, "Influence of backfill on coal pillar strength and floor bearing capacity in weak floor conditions in the Illinois Basin," International Journal of Rock Mechanics and Mining Sciences, vol. 76, no. 6, pp. 55-67, 2015.

[11] Q. L. Chang, Research on Theory and Practice of Mining Induced Overlying Strata Deformation and Surface Subsidence with Paste Backfilling, China University of Mining \& Technology, Xuzhou, China, 2009.

[12] X. X. Miao, F. Ju, Y. L. Huang, and G. L. Guo, "New development and prospect of backfilling mining theory and technology," Journal of China University of Mining \& Technology, vol. 44, no. 3, pp. 391-399, 2015.

[13] Q. L. Chang, H. Q. Zhou, J. B. Bai, C. R. Duan, and Y. W. Li, "Stability study and practice of overlying strata with paste backfilling," Journal of Mining \& Safety Engineering, vol. 28, no. 2, pp. 279-282, 2011.

[14] Y. Ding, G. M. Feng, and C. Z. Wang, "Experimental research on basic properties of superhigh-water packing material," Journal of China Coal Society, vol. 36, no. 7, pp. 1087-1092, 2011.
[15] G. M. Feng, K. J. Jia, and B. B. Shang, “Application and prospect of super-high-water packing material in mining engineering," Coal Science and Technology, vol. 43, no. 1, pp. 5-9, 2015.

[16] M. Li, J. X. Zhang, and H. Q. Jiang, "A thin plate on elastic foundation model of overlying strata for dense solid backfill mining," Journal of China Coal Society, vol. 39, no. 12, pp. 2369-2373, 2014.

[17] K. J. Jia, G. M. Feng, H. J. Li, and J. Li, "Research on superhigh-water material filling mining in thin coal seam through similar simulation experiment," Journal of China Coal Society, vol. 38, no. 2, pp. 267-271, 2013.

[18] B. G. Yang, J. Yang, Y. K. Wang, and X. X. Yang, "Research on filling mining overburden movement deformation," Journal of Xian University of Science \& Technology, vol. 35, no. 6, pp. 732-737, 2015.

[19] M. G. Qian, P. W. Shi, and J. L. Xu, Mining Pressure and Strata Control, China University of Mining and Technology Press, Xuzhou, China, 2010.

[20] Z. L. Xu, A Brief Course in Elastic Mechanics, Higher Education Press, Beijing, China, 2013.

[21] H. Z. Shan and C. F. Xie, "Engineering mechanics," in Statics and Material Mechanics, Higher Education Press, Beijing, China, 2004. 


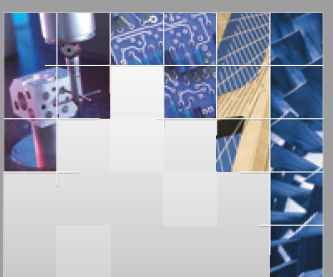

\section{Enfincering}
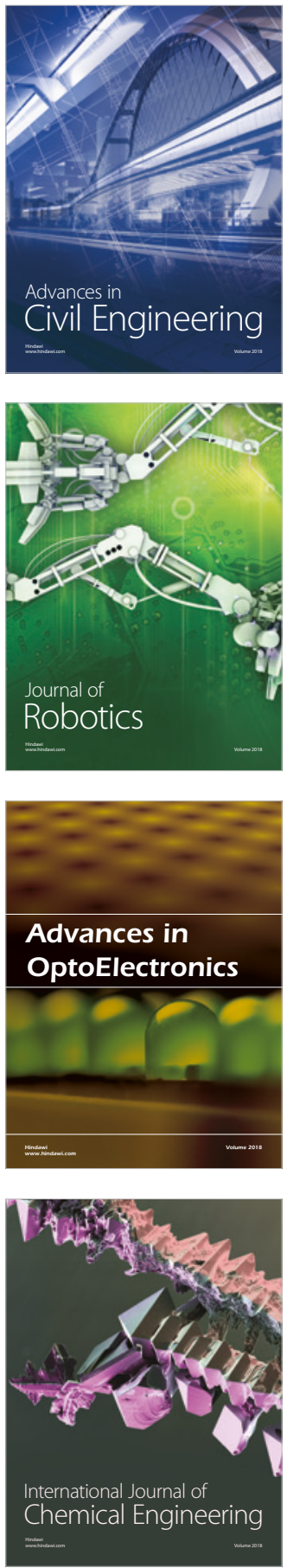

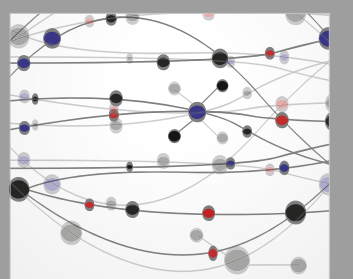

\section{Rotating \\ Machinery}

The Scientific World Journal

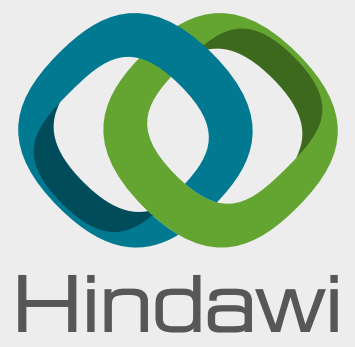

Submit your manuscripts at

www.hindawi.com
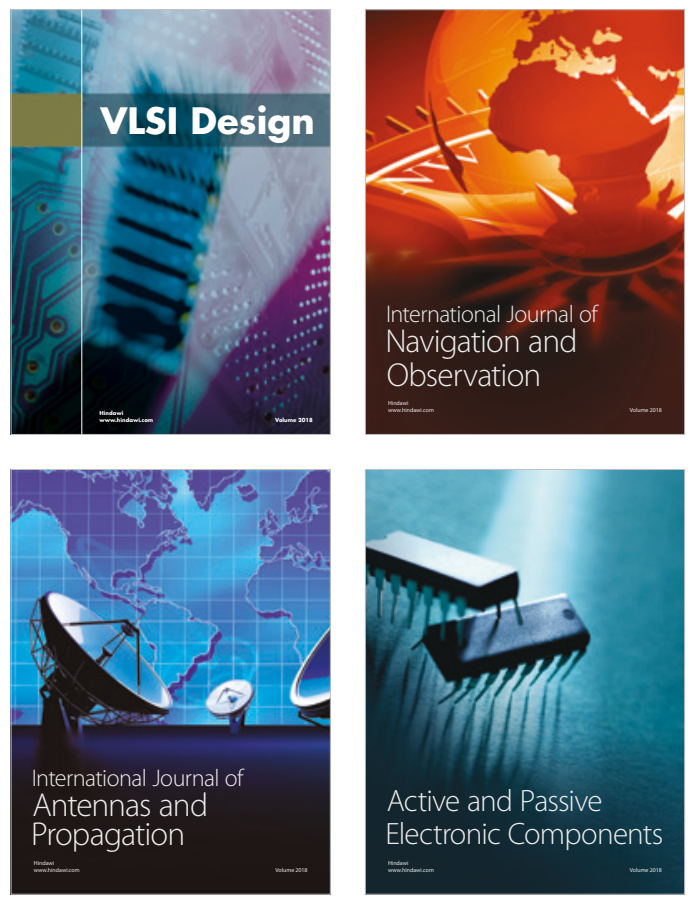
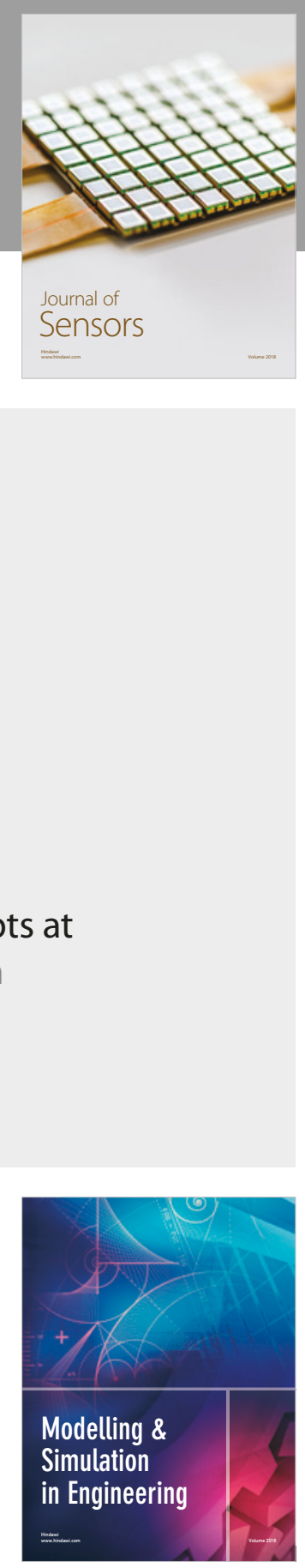

\section{Advances \\ Multimedia}
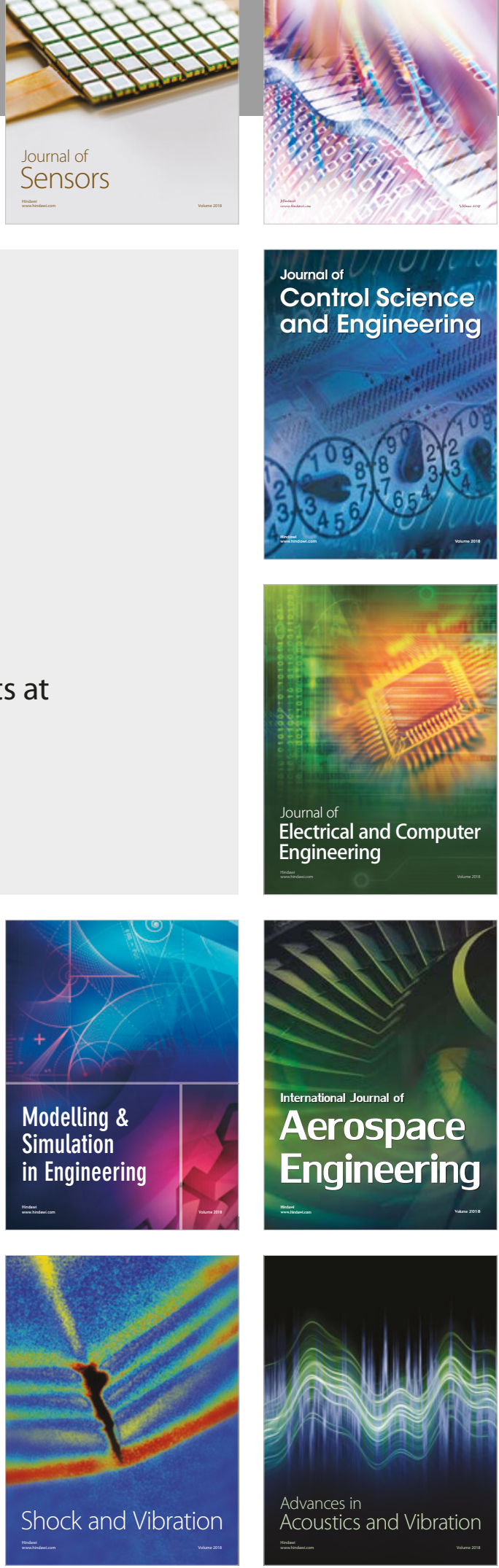